\title{
WAY OF THE WARRIOR: BATTLING ISSUES OF INTERLOK WITH THE SWORD OF WISDOM
}

\author{
Lalita Sinha \\ lalitasinha@yahoo.com
}

School of Education, Language and Communication

Wawasan Open University

\begin{abstract}
Abdullah Hussain's novel, Interlok, has been the source of discussion and conflict among various factions in the multi-ethnic and multireligious community of Malaysia. As an alternative to some of the current negative impressions of the book, and accusations directed at the author, this essay presents a view of the novel and of the author's motivations. It draws on two elements, evidences from the text itself, and an inward level or esoteric interpretation of the text. From an approach of Hindu religious and spiritual doctrines, and universal metaphysical truths from a Traditionalist perspective, it concludes that a fair and unbiased textual analysis which foregrounds Truth allows a genuine reader to understand what the author actually wrote, and to see beyond the conflict and accusations.
\end{abstract}

Keywords: Hindu esoterism, discernment, Traditionalist perspective, human integration 


\section{Introduction}

Scriptures of the world's major religions are in concord about one thing: all exhort man to know his quest or purpose of life, which is, to know one's true nature. In Hinduism, this involves discernment of the Real and the illusory, or between the Eternal and the temporal. Ultimately such knowledge leads man to wisdom, and realisation of the Absolute, Truth, Ultimate Reality or any of the well-established references to God.

It is commonly agreed that there are two opposing elements in constant tension within the human being-consciousness of the perfection and boundlessness of God (brahmavidya), and in opposition to that, ignorance (avidya) or unconsciousness, which is, human imperfection and limitation and the relativity of the created, physical universe. Man is in this imperfect world by default of his own imperfection, and his mission or quest in life is therefore to find the path of return to his original, perfect and divine nature. This ideal, constituting the underlying universality expressed in different ways in all spiritual traditions, has been referred to as religio perennis (Schuon, 1984:137), where religio (religare) is a "bind", that is, religion binds or links the human to the Divine, and perennis meaning, eternal. Thus in the perspective of religio perennis, every authentic religious tradition leads one back to the Eternal, or God.

Today in Malaysia, Interlok, ${ }^{1}$ a novel written by Abdullah Hussain, a National Laureate, has been the source of a seemingly irresolvable situation with religious and ethnic overtones in our multi-ethnic and multi-religious community. As an alternative to some of the current negative impressions of the book that are proliferating, and the accusations of deliberate disparagement of Indians directed at the author, this essay presents a view of the novel and of the author's motivations, based firstly on evidences from the text, and reinforced by an inward or esoteric interpretation of the novel. The aim of the paper is to discover, from an unbiased stance, whether there is any justification for the impressions and accusations being made. The arguments rely on the foundation of Hindu religious and spiritual doctrines and methods, and on the Traditionalist perspective of metaphysical truths.

Towards this aim, the paper will proceed in two major sections. The first section will provide an explanation of several doctrinal aspects of the Hindu religious tradition. It will focus on concepts that are relevant to discerning between the "real" as opposed to "the Ideal". For this purpose, four relevant meta-textual aspects of the Hindu worldview will be explained, that is, the 
conceptualization of God, the traditional view of man, the spiritual concept of man's subsistence in God, and the inviolability of a literary work. The subsequent section will conduct a textual analysis of specific elements in the novel, reflecting both the vertical connection (i.e. man's connection with God), and the horizontal connection (i.e. man's connection with his environment) as they are portrayed in the novel, as they appear through the lenses of the Hindu doctrines explained. In the final part of the essay which is the conclusion, certain insights gained from the selected passages from Interlok will be forwarded, to refute the accusation that the author, Abdullah Hussain, presents a disparaging view of Indians in the novel.

\section{The Real and the Ideal}

Ananda Coomaraswamy, a stalwart of Traditionalism, states that

...the most urgent practical task to be resolved ... is a control and revision of the principles of comparative religion, the true end of which ... should be to demonstrate the common metaphysical basis of all religions. (1952:15859)

Frithjof Schuon, forerunner of the Traditionalist perspective, explains that intellectual understanding entails a spiritual responsibility, and that requires to be complemented by sincerity and faith, and that "seeing" (in height) implies "believing" in depth (Stoddart, 2008:26). In other words, the greater our perception of essential and saving truths, the greater our obligation lies towards an effort of inward or spiritual "realisation". As elaborated by Oldmeadow on Schuon's view, each branch of humanity exhibits a psychic and spiritual homogeneity which may transcend barriers of geography and biology (Oldmeadow, 2007:6).

"The real" (with a small " $\mathrm{r}$ ") may be understood to refer to human or worldly realities, and human beliefs and practices in the physical world. Stated differently, we are referring to truths, or interpretive, human views of reality, including subjective views of religion. On the other hand, "the Ideal", sometimes referred to as "the Real" (with a capital "R") refers to Divine Realities and Principles; in other words, knowledge that is Divinely revealed or disclosed, including immutable Truths. Hindu spirituality, like most other spiritual traditions, exhorts man to fulfil his quest: to proceed from the real to the Ideal. This quest may be achieved through prescribed doctrines and methods. The doctrine of four "paths to God" (marga), or 
types of union with God (yoga), terms the methods of the paths to union as karma, bhakti, raja, and jnana. Essentially, although these are four different means or modes of realisation, they are integral to one another, whether consciously or not, their path merge at the common point. An analogy may be drawn from four human faculties or capacities: through the intellect (buddhi), realisation is gained by the acquisition of wisdom and knowledge (jnana); or through the heart ( $h r d)$, or emotion and devotion (bhakti); or the mind (manas), through meditation and mastery of self (raja); similarly through mastery of the body (sarira), by devoting all of one's efforts to service and action (karma).

The Bhagavad Gita (henceforth BG), one of the most well-known Hindu scriptures, exhorts: Be a warrior. Kill desire. Kill with the sword of wisdom. It is most challenging to consider that the whole of the scred text of the Hindus is an exhortation to active, dynamic battle on the path to realisation. This is precisely the "warrior" who "battle", reffered to in the title of this essay. Such an idea of encouragement of war may appear to run contrary to the much more well-known, popular impression that Hinduism is a peaceful, passive and reflective religion. Yet verse after verse of the BG, constituting the advice of Shri Krishna (or God, disguised as a charioteer) to Arjuna (representing man), to stand up and do battle (yudh), fight, engage in conflict, and thereby fulfil his destiny (or dharma) as a warrior, at the Battle of Kurukshetra. The Traditionalist view on battle has been explained in a similar context, i.e. of the wars in Islam in which the Companions of the Prophet were engaged,

... and the holy men who fought in this manner, far from fighting against individuals and human interests, did so in the spirit of the Bhagavad Gita; Krishna enjoined upon Arjuna to fight, not out of hatred nor even to conquer, but in order to fulfil his destiny as an instrument of the Divine plan and without attaching himself to the fruits of his actions ...

(Schuon, 1975:107)

The seemingly contradictory religious ideals-of activity vs passivity or, war vs peace-may be resolved through an analogic and symbolic interpretation. That is, "Battle" is interpreted as the battles of life, both abstract and concrete; "Kurukshetra", meaning battlefield ( $k u r u=$ field, shetra = battle), represents man's body as the "battlefield" and the enemies/warriors facing one another are none other than the (higher) Self (paramatman, the divinity in man, God- 
realisation, the Spirit) battling the (lower) self (jivatman, the ego, the senses, the worldly self, negativity). The weapon, or defence of the warrior, then, is discernment. That is to say, that man uses not the destructive, physical or verbal weapons against the other (man), but the beneficial, intellectual, spiritual weapon-the sword of wisdom-against tendencies and ignorant, egoistic motivations within his own self, or the ego, "desire" as is defined in Hinduism, to fight the battles of life. Therefore, the Sword of Wisdom is the ability of discernment between the Self against the self that is to be wielded in battling one's existential issues. Contrary to this stance is the focus on outward, formalistic understanding and practice, and exclusivity directed outwards (rather than at the self), that has led to the deep schisms within the great religions of the world, including in Hinduism.

The discussion in the essay will begin with a brief explanation of Hindu doctrines relevant to an understanding of the "offensive" textual and metatextual elements in Interlok. These are, the doctrine of Trimurti, of varna, of Paramatman/jivatman, and finally that of adikarya. ${ }^{2}$

\section{Trimurti and the conceptualisation of god}

The Sanskrit term for religion or Hinduism in particular is sanatana dharma. In brief, it means, the eternal (sanatana) cosmic order, and duty or obligation (dharma). Literally, dhar, which means to hold or to bind, corresponds with the meaning of the English word, religion (Latin, religaire). Thus, religion or sanatana dharma is the binding or attaching of oneself to one's divine origins by upholding the eternal, divine order. In Hinduism, there is a wide variety of means to bind oneself to one's divine origins. It ranges from a hierarchical conception of God-from ritualistic and popular worship (referred to as saguna or inherent qualities and attributes) of multiple "gods and goddesses" (333 001008 to be precise)-to the spiritual realisation of, or identification with, the transcendent Brahman, the One, Ultimate Reality (referred to as nirguna, or "beyond qualities").

Between the highest and lowest levels of hierarchy, Hindu forms of worship focus on the concept of Trimurti (literally, three (tri) faces (murti), the iconic representation by which Hindus identify three key aspects of Brahman in the created world and nature, namely, Brahma (or Creation), Vishnu (or Sustenance), and Shiva (or Destruction). In the spiritual or esoteric understanding, the Trimurti or three aspects have two discrete energies, the masculine and the feminine. In religious practice, Trimurti is represented 
by what is popularly referred to as "idols" or "gods and goddesses" referred to as devata (or deities), or a particular god(dess) (ishta deva/ishvara). Essentially, deities are anthropomorphic representations of hypostases or Divine beings, that is, energies or powers, and each represents a specific aspect of Divine energy or power. For example, Saraswati and Lakshmi are divine feminine energies that embody, or are specifically associated with particular Divine Energy. Saraswati represents knowledge and wisdom (which includes the arts/artists), and Lakshmi with abundance (including material wealth and spiritual plenitude).

The levels of God-man connection are bidirectional, that is, God makes Himself known to man through Divine Grace, through the process of descent (avatara) into the human plane; and man comes to understand God, according to the individual's (jiv-atman) effort and stages of knowledge of God through a process of ascent to ultimate union with God/Divinity (Paramatman). Thus Divine Grace and human effort function is in correspondence. This idea is often expressed in the maxim: God becomes man, so that man can become God. Simply stated, whether the Hindu consciously acknowledges and worships 333001008 "gods", he is still ultimately referring to Brahman, and even if he directs his focus only on Brahman, he still essentially encompasses, ultimately, the 333001008 "gods". This number is merely indicative of the infinite characteristics of Brahman. This is the point of common misunderstanding both among Hindus and non-Hindus about the unity/multiplicity of God, which may be clarified by summarising it thus: Hindu worship is directed to God THROUGH devata, not TO devata. This is the essential function of iconic representation, and the "defence" of "polytheism", the popular worship of "many gods".

\section{Varnashrama-dharma and the stations of man}

In the preceding paragraphs, we have understood the divine hierarchies. In a similar vein, there also exists a series of human hierarchies, or different orders and stations in human life, which is consistent with the claim that in Hinduism, the whole of man's life is a series of transitions from one state or station to another, in his journey from the real to the Ideal.

Vedic literature confirms that the principle of varnashrama-dharma, the traditional, hierarchical classification of society, is consistent with the sustenance of cosmic order (dharma). Varna, literally meaning colour, refers to the "colour" of human qualities (guna) or tendencies, or aptitudes, 
which proceed from Krishna Himself (a manifestation of Brahman). There is much scriptural evidence of this:

According to the three modes of material nature and the work ascribed to them, the four divisions of human society were created by Me.

(BG, 4:13)

Furthermore, it is specified that according to the Ideal:

There is no superior caste. The Universe is the work of the Immense Being. The beings created by him were only divided into castes according to their aptitude.

The above extract reflects the ideals of the classical Vedic tradition of several thousand years ago. However, in the post-classical period, Hindus began to be rigidly ordered on a social basis that became stratified, contrary to the original spiritual basis of varna which emphasised complementarity as the key to maintaining balance and order in society. Higher and lower castes thus became strictly differentiated as higher or lower social classes. This practice was endorsed and officially documented during the British colonial period of Indian history. Today, the reality is that the caste system has become the subject of much perversion and abuse, and the source of intense criticism against Hinduism. Thus the English term "pariah" may be attributed to such developments. In the main, it has raised the question: If varna proceeds from religion or a Divine scriptural order, how could that (or any) religion create and perpetrate social discrimination, and even racial polarisation and prejudice?

To address this question, it should be known that varna was traditionally a divinely-ordained, hierarchically ordered social system that rested fundamentally on the acknowledgment of differences in aptitudes or human personality types and existential states of individuals. In other words, certain individuals possess certain predominant qualities, such as leadership, industriousness, physical stamina, or monetary skills. In relation to personality types, since the path of the individual is meant to be a journey to perfection, varna recognises that there are different paths to perfection, determined by personality type and/or role in society. For example, active people perfect 
themselves through selflessness and dedication to work; intellectual people do so through teaching and study (Molloy, 2002:74), and so on. The varnas are essentially natural categories in every human civilisation. Accordingly, the jiva or soul attains a body situated in an appropriate mode of nature. In fact, society becomes successful only when these natural orders cooperate for spiritual realisation (Goswami,1977:66). The hierarchy of human types and tendencies may be understood exoterically as a social order with each order having a specific function in the service of society, and at the same time, esoterically as spiritual paths.

For purposes of our discussion, we may start from the premise that human beings have been created according to four major tendencies or qualities. The life of a brahmin is concerned with things of the mind and spirit, and a keen intuitive grasp of human values (Smith, 1991:56). These are the intellectual, philosophical, and spiritual leaders in a civilisation (Smith, 56). Thus scholars, teachers and priests who traditional role in society have proximity with religion, rituals, learning and wisdom are highly regarded in society. However, on a spiritual level, the real brahmin or brahmana is the seer, or realised soul. That is, one who knows the Brahman is called a brahmin.

Next, the kshatriya (literal meaning, "endowed with sovereignty"), constitutes kings, leaders, administrators and warriors, who are to be respected for upholding righteousness. One such function lies in their role as guardians and protectors of the weak and helpless. Kshatriya is an inflection of the root word kshet- which means any form of hurt or pain. Thus kshat-riya is one who protects or delivers another from pain. It includes two interrelated notions, namely kuru-kshetra, and dharma-kshetra or dharma-yuddha. The first term, kuru means "place", or "field" or "body", and kshetra/yuddha is "battle." Hence, kuru-kshetra, is understood as "battle-field," that is, the human body-mind-spirit which is constantly a battleground between vidya (knowledge or good) over avidya (ignorance or evil) in man. For the chivalrous order of man, referred to in Hinduism as the warrior caste or kshatriya, war and life are synonymous (Guenon, 1995:286). Spiritually, the term kshatriya refers to every spiritual seeker who battles in the cause of dharma, order or Truth.

The specific function and role of a vaishya (meaning, producer) in society is to provide human physical and material needs on which the worldly life depends. Therefore, people of the vaishya caste have the specific tendency or skill in creating the things that are needed. "Farming, 
protection of cows and business, are the qualities of work for the vaishya" (BG, 18:44). Although a vaishya is primarily involved in the production of food, he is also responsible for economic well-being. In Vedic society, wealth especially meant cows, dairy and agricultural products. This caste also includes artisans, farmers, tradesmen and herdsmen.

In traditional Hindu society, the primary function of the sudra is to render manual service (seva) to the other three castes, through hard manual labour. A sudra is a man with "no propensities for intellectual, military or mercantile life" (Goswami, 68). Nonetheless, labour and devoted service under supervision is provided to the whole of society by the sudra caste (Smith, 56). In this connection, the Gita assures that every social order can attain the supreme goal of unity with the Ideal: "Those who take shelter in Me, although they may be lower birth, can approach the supreme destination" (9:32).

It should be noted that each of the four major classifications as explained above has become, through time, further subdivided and categorised according to tendencies/occupation. Of special relevance to this essay is a social subgroup of sudras, who used to be called Parjanya, alternatively spelled as Paraiyar (or pariya, parayar or sambavar). The preferred name is adi-dravidar (meaning original or first, Dravidian), used in the south Indian states of Tamil Nadu and Kerala (see, "Paraiyar" in Wikipedia), and dasa and $n a n d a$, in the north Indian states. It is interesting to note that originally, dasa or das meant "slave" or "servant" in an exclusive context: as "slave of God" referring to the spiritual seeker who bows to none but God. This term evolved to be used to identify people of former "untouchable" castes or "dalit". Again, certain facts of "the real" matter may be mentioned: First, the Sanskrit word "dalit" means "ground", "suppressed", "crushed", or "broken to pieces". Second, Gandhi coined the word Harijan, translated roughly as "Children of God", to identify the former dalit. Third, the terms "Scheduled Castes and Scheduled Tribes (SC/ST)" are the official terms used in Indian government documents to identify former "untouchables" and tribes. This practice is a carry-over from the British colonial rule that is to be "given credit" for undertaking the immense task of concretising and fossilising social discrimination and abuse by initiating their documentation. Thereon, pariyar has been associated with the derogatory English word, "pariah", defined as "member of a low caste; social outcast" (Oxford English Dictionary, 1989). This is certainly in line with the ingenious policy of "divide and rule" that assured the colonials of power for hundreds of years 
over their native subjects, whether politically or psychologically, till today. J.H. Hutton used the term, "exterior" (or outside) to refer to these castes as they were outside the gamut of the Hindu pantheon. He points out that,

It is not intended that the term should have any reference to occupation as such but to those castes which by reason of their traditional position in Hindu society are denied access to temples, for instance, or have to use separate wells or are not allowed to sit inside a school house but have to remain outside, or which suffer similar such social disabilities. (1980:193)

In light of this situation, a current reality is that today in India, the divide between "upper" and "lower" social classes is as firmly entrenched as ever. Kancha Ilaiah, a political science professor, in his landmark book (1996), examines the 1990s upsurge of "Hindutva", the group that claimed responsibility for the demolition of the Barbri Mosque. Certain political parties and organisations, and occasionally, the government itself, became the exponents of aggressive "Hinduism" under this flag. People were told to identify themselves with a purist and racist form of Hindu supremacy. In fact the so-called pride of Hindutva rests on hatred towards Muslims, Christians, and Dalits. Kancha describes this phenomenon as "not merely surprising but shocking" (1996:xi).

In understanding the spiritual foundation for the classification of human society, two specific aspects should be noted. Firstly, the classification is not rigid or exclusive, or intractable. For example, according to the doctrine of reincarnation (punar janam) the kshatriya who declines to fight has not fulfilled his true dharma or purpose for which he was granted human birth, therefore he is a kshatriya only in name. Similarly, a brahmin who commits impious acts is a brahmin only in name. Both will have to be born again to fulfil their preordained purposes; by the same token, a sudra who fulfils his purpose of servitude to the best of his ability may be reborn as a brahmin in another lifetime.

This may be evidenced from the list of numerous paraiyars who have gained recognition as outstanding historical and political personalities, including musicians, scholars, social reformers and activists. Among the most illustrious in ancient times is Thiruvalluvar a celebrated Tamil thinker/ poet who wrote the Thirukkural, a classic on ethics. Another example is the lineage of the Maurya dynasty. The grandfather of the great emperor Asoka, Chandragupta Maurya, who united vast regions of the Indian subcontinent in 321 B.C., was said to have been born of sudra parentage. A celebrated 
modern-day paraiyar musician is Ilaiyaraaja an Indian film composer, singer, and lyricist. In the context of society constituting different parts of the body of Brahma, paraiyars belong to the Right-hand (or valangai) faction made up of castes with an agricultural basis. Thus, there is glory in the title valangai-mougattar, or friends of the Right-hand. Indeed there are glorified accounts of their lineage with the brahmin and the vaishya. These are actual evidences of the ambivalence of the varna system.

The second aspect of the spiritual basis of caste is that, due compensation is provided for services rendered by the lower caste to the higher. This has been explained with the following analogy: The wage earner who checks out at five o'clock is through for the day; whereas the employer must take home the ever-present insecurities of the entrepreneur, and often homework as well (Smith, 1991:57). Moreover, justice and equity are defined as condition in which privileges are proportionate to responsibilities. For the same offence, the punishment of the vaishya should be twice as heavy as that of the sudra, that of the kshatriya twice as heavy, and that of the brahmin twice or even four times as heavy (Coomaraswamy, 12). However, on the path to the Ideal, one is bound for freedom from all varnas and ultimately, moksha, liberation from any further rebirth.

The norms of domestic, social, and religious life are set out in the Hindu canon on ethics, Manu dharma shastra (Laws of Manu), which Hindus consider a revealed text (smrti). According to this text, an ordered society rests on the notion of society as a holistic entity: every type or caste of society is analogous to the human body which was created in the image of the "body" of Brahma, or Adi Purusha (Foremost or Perfected man). In this conceptualisation, like the human body, every caste has a specific and crucial function and position, and none can function fully by neglecting the other. For example, without the assistance of manual labour of the sudra, the other castes would not be able to complete their role, just as without legs a human being becomes immobile; the kshatriya needs the vaishya to provide the neccessities so that his function as protector of the society may be fulfilled, for human life itself cannot be sustained without food, and so on. Thus, though there is a social hierarchy, there is an essential equity at every level of society, because each is interdependent on, and complementary to, the other. And the responsiblity for establishing an ordered society is required to the extent of the capability of each level. This involves an integration, not a division of society, that is internally 
democratic and outwardly answerable to other groups for the fulfilment of their own function (Coomaraswamy, 1971:156).

In this understanding, the emphasis on the meaning of the word "different" may be reiterated: four different castes simply means that the castes are "not the same"; it does not mean that anyone caste is "better" or "worse". Thus, difference is divinely preordained, and by recognising and acknowledging this, each individual knows his duty in society, such that it can function as a whole, but keeping to a prescribed, hierarchical order. The ultimate goal of each varna is to achieve the Ideal, that is, to return back to God. Yet, as is true of all religions, there is a gap between traditional principles of the religion that have endured, and practices induced and introduced by materialism, secularism and modernity, that have caused degeneration and decadence in the caste system in particular, and the Hindu religion, in general.

\section{Sat-Cit-Ananda, man's subsistence in god}

Beyond the relationship of duality of the individual self or soul (jiv-atman) and the universal Self/Spirit (Param-atman), the Hindu view of reality at the highest order maintains the idea of unity of the self and Self. In Vedic scriptures, man is instructed to identify himself with the Atman in him, which is none other than Brahman in man (Zailan Moris, 2000:77). Thus the sole purpose of human birth is to gain experience and gather positive karma that will return one to the original state. This recalls the mystical articulation of God-realisation, aham Brahasmi (I am Brahman). For as long as man continues to identify with maya or the created universe, or "the real" that is finite, temporary, material and tangible, he will continue to gather karma and remain in samsara, the cycle of births and deaths. However, through intuitive knowledge (prajna), he recognises the self is in fact the Self, which is infinite, eternal, transcendent and absolute, and thereby gains consciousness of the perfection of his true, original nature. This knowledge leads to moksha, liberation from samsara (Zailan Moris, 2000:77).

In Hinduism, the state of ultimate consciousness is referred to by the term, Sat-cit-ananda (or saccidananda), or Truth-Consciousness-Bliss. Saccidananda comprises two final stations (samadhi) of the soul: annihilation of the ego (nirvikalpa samadhi), and identification with the Supreme (maha samadhi). The soul starts out as an All-Knowing entity, and in human birth, through remembrance, (smrna) returns to it. The vision of identity with Brahman is always in existence, timelessly, and yet obscured by 
forgetfulness and ignorance. One needs an agency-the Logos-which in Hinduism, is conceptualised through the Trimurti and actualised through sraddha (devout faith). Sraddha removes the veil of ignorance, that will enable entry into gnosis, a station of knowledge of one's identity with Brahman (turiya) (Sivaraman, 1989:xvii).

The vertical connection (between man and God) involves renunciation (tyaga) of the ego or the self; at the level of the horizontal connection (between man and his environment), it involves renunciation of selfishness, anger, pride and desires. In both cases, logically, if there is no "self", there is no "other", often explained as the absence of the subject/object split. This state is often articulated by the mystical expression "I am you". When this is achieved, when one can "lose" oneself, one becomes awakened to, and united with, the spirit of the whole universe. Thus one becomes the One (Brahman). The BG says:

I pervade the entire universe in my unmanifested form. All creatures find their existence in me, but I am not limited by them. Behold my divine mystery! (9:4-5)

Attainment to this level of consciousness is manifest in the absence of emphasis on "I" and the exclusivity and religious extremism committed in the name of (my/the only) God. Rather, emphasis is purely on "none but God", whereby, as has been stated earlier, man subsists in God. This viewpoint reduces human issues, values, events etc., to an inconsequential level.

\section{Adikary $a$ and the inviolability of a literary work}

In the current context, Literature, that is literary works which inhere certain qualities and embody certain principles are considered works of art, similar to other works of art such as sculpture, music, architecture, and poetry. It is relevant and necessary to communicate an important remaining concept in this regard, that is, the meta-textual aspect of a literary work, primarily because it is a literary work that lies at the heart of the present conflict and to the issue at hand, namely to establish the inviolability of Interlok.

A culture defines or represents itself through its works of art. From the spiritual Hindu viewpoint, which is consistent with the Traditionalist perspective, a literary work which conforms to, and manifests, certain aesthetic and devotional principles, is referred to as adikarya, generally 
translated as "great work" or "classic", and forming part of the literary canon of its culture of origin. Furthermore, the substance or contents of the adikarya constitutes shastra, or knowledge attributed to a divine source, and revealed to the author through insight or intuition. Thus, poets and authors were held in an exalted position in society, for the precise reason that they function as channels for the production and dissemination of shastra, which embodies qualities such as truth and beauty. Therefore, they are known as adikavi (foremost or perfected poet).

The Traditionalist perspective reveals a nexus between belief and aesthetics. There is a close link between religious devotion, or "the Ideal" (meaning metaphysical principles) and the of art and its appreciation, or "the real" (meaning the social and secular dimension). The link lies in the ontological role of art in its audience, which functions beyond the limits of language and representation, to engender man's remembrance of his essential, original nature. Ultimately, the role is to create an experiential knowledge of his inviolable connection with God. Simply stated, art has the potentiality to satisfy man's desire to unite with God. In Hinduism, the role of dharma, or the bind of religion (both nirguna and saguna aspects) and the role of adikarya are synonymous. Therefore, in mentioning art, we are referring to sacred art.

Essentially functioning as a trope or icon, sacred art communicates the sacred dimension into the secular, that is, it draws its audience back to the sacred by its very nature. Traditionally, on the part of the audience (sahrdaya), it involves participation and engagement. To clarify the connection between author and audience, it may be said that an enlightened author consciously and unconsciously "encodes" meaning in a text, and his audience "decodes" that meaning. Both have as basis, a shared universe of discourse. In other words, a piece of art produced in guidance of the tradition or truth it is expressing, is at the same time, a human consecration to the Divine. Furthermore, it acts as a symbol of man's connection with the sacred.

In the above context, it may be understood why the adikarya and the adikavi are exalted in the Hindu tradition. In relation to the religious tradition, and particularly the concept of Trimurti in that man identifies himself with his Creator through iconic representation, it was mentioned earlier that the Goddess Saraswati is the divine feminine energy that embodies, or is specifically associated with, knowledge, wisdom and (refined) speech (thus including the arts/artists). Therefore, in ritualistic worship, the Hindu religious tradition places great emphasis on the book. In other words, in 


\section{MALAY LITERATURE}

the Hindu view, the function of a statue of Saraswati and that of a book are synonymous, in that both are duly venerated as symbolic representations, or as embodiments, of the highest knowledge. Based on these ideals, we will examine the situation with regard to Interlok and its role and function in Malaysian society in a subsequent section.

\section{The Real and the Ideal in Interlok}

Progressing from a grasp of the foregoing Hindu traditional doctrines of discernment between "the real" and "the Ideal", some of the issues related to Interlok will be discussed in this section from a premise of acceptance that these two realities exist concurrently. Though the novel addresses many different types of connection between characters of the major ethnic groups of Malaysia, our discussion will be confined to the Indian/Hindu portrayal in the novel, including the interaction with "the other" (i.e. the Malay characters) since these are the source of issues of discord and disharmony. This will be critically analysed, with textual evidences, ${ }^{3}$ and read in the light of explanations of Hindu doctrines and Traditionalist perspectives in the foregoing section. They are presented according to two broad themes which are interrelated, that is, the vertical connection or that of man and God, and the horizontal connection, that of man and his environment, as may be interpreted from the novel. It is relevant to point out here that the vertical connection is seen as a higher or meta-order that is central to the esoteric viewpoint, and one that shapes the nature of the horizontal connection. An extra-textual issue will also be examined, namely, the status and role of the novel and the viewpoint of the author, Abdullah Hussain, in Malaysian society, primarily based on the Hindu explanation of the role of a literary work in the preceding section, and augmented by the textual evidences. Essentially, the objective is to bring to light the unitive view of the novel, which this essay claims is consistent with the viewpoint of the author.

\section{The vertical connection}

Analysis shows that the author gives due emphasis to the position of religion and God in the novel. This is equally true of the Indian characters (or the self) as it is of the non-Indians (or the other). Religion and ethnicity represent the grid along which the Indians assess and evaluate the other vis-á-vis the self, even before direct encounter. For example, in the mind 
of the Indian character (one of the protagonists), Maniam, who comes to Malaya in search of a better life, there is both affinity and disparity between "us" and "they":

Orang kampungnya juga bercerita.... Anak negeri yang akan didatanginya itu baik-baik belaka. Mereka makan nasi dan kari seperti kita juga .... memakai kain macam kita, memakai kopiah seperti orang Muslim, mereka beragama Islam. (p. 212)

(People from his village too, said that ... the people of the land where he was bound are all good people. They ate rice and curry just like us, ... wore clothes like ours, put on the skull cap like Muslims would, they were Muslims.)

In terms of affinity, firstly there is a positive regard for the other, who are "all good people", and secondly, there are shared cultural traits in the form of clothes and food, which are "just like us." Yet the author presents the difference in terms of religion: "they" are differentiated from "us" by apparel, i.e., the skull cap, indicating "they were Muslims". From this example, it may be seen that the author constructs two separate and different entities that, at the same time, have shared traits.

The above view of the Malay, is consistent with the one that Maniam forms on encounter with the anticipated "good people". This may be seen as a "pull factor" that is, what is attractive to him about the foreign land. It is reinforced by a "push factor", also determined by ethnic and religious overtones. In a flashback, when he considers what living conditions at home have been like, Maniam realises,

Penduduk sudah padat dan Maniam berasa sudah terlalu sempit baginya untuk mencari makan.... salah seekor lembu jantannya yang digunakan untuk membajak sawah telah tua dan tidak dapat digunakan lagi. Lembu itu menunggu masa untuk mati sahaja. Sebagai orang Hindu, lembu tidak boleh disembelih dan dimakan dagingnya. (pp. 214-15)

(It was already congested with people and Maniam felt it had become too overcrowded for him to make a living ... one of the male cattle that was used for ploughing the land was already too old and no longer useful. It was merely waiting for its time to die. A Hindu is forbidden to slaughter a cattle for food.) 
There is already not enough place for him, which is a "push" from his own community and country, there is insufficient food, a "push" from a religious standpoint. In relation to the push factor of religion, the author presents a reality of the worldly life here: Maniam and his community are grappling with the predicament of survival, faced with a choice between sustenance of the body and maintenance of a religious conviction.

In determining or judging the worth of a literary text, one may look at the approach, or analyse the rhetorical context; for instance, what is the writer's position as conveyed by the text. Much has been said about a derogatory portrayal by the author, of the Indian and his religion in the existing on-going discourse and dispute in relation to the issue of the sacred cow in Hinduism. But in the example quoted above, it is difficult to find any of that. On the contrary, the diction is neutral and matter-of-fact, yet tinged with an unmistakable poignancy, conveying it as a complex, universal dilemma. Rather than having Maniam going against his religious belief, the author masterfully steers him, and others like him, through an alternative route, i.e., migration. Indians have voiced objection to being called pendatang, migrants. Based on "the real" facts of history, Indian migration to Malaya is an undeniable reality. Based on "the Ideal" it is an issue of human needs, of his frailty and his resilience, and his will to survive. Furthermore, a person who migrates is a migrant (pendatang) and the word has no derogative connotation universally, as well as in the novel. From the choices made, Maniam manages to affirm both needs, of body and of spirit. Here, the human spirit overcomes the dilemma. Understanding his plight, the author accords him dignity.

In a similar vein, the objective stance may be seen from the author's informed position about Hindu religious practices and their contexts. One is the traditional Hindu gesture of greeting and parting, namashkar (Sanskrit) or vannakam (Tamil) which is the same gesture also used in the ritual of prayer. When Maniam parts from his wife in India, she makes that gesture:

Sebagai isteri yang taat yang juga menginginkan kesenangan hidup, maka dengan menyusun jari kedua-dua belah tangannya dia mengizinkan suaminya berangkat. (p. 216)

(As a faithful wife who also wanted a comfortable life, she saw him off by placing both her palms together gesturing to her husband her approval.) 
Further on in the narrative, in an incident in which Maniam shelters and provides for Seman, the young son of his Malay friend, Musa, who has passed away, and for Musa's widow, Mak Limah, Maniam conveys the same gesture of respect to "the other", i.e., Mak Limah:

"Berehatlah dulu," kata Maniam. "Saya mahu pergi kerja." Maniam menyusun jari kedua-dua belah tangannya memberikan hormat kepada Mak Limah. Mak Limah tidak tahu apa-apa yang mesti dibuat. Dia melihat Seman ... . (p. 297)

("Do take a rest," said Maniam. "I'm going to work." Maniam put his palms together, showing his respect for Mak Limah. Mak Limah did not know what the appropriate response should be. She looked at Seman ...)

A Hindu who knows the significance of the gesture would appreciate the passage as an authentic portrayal of a very important aspect of Hindu culture. From an esoteric understanding, the Ideal behind the traditional Hindu form of greeting may be explained as follows: folded hands are raised to the forehead, at the point of the third eye, or ajna chakra a foremost centre of energy in the human body. The ajna chakra is the seat of discernment between discursive, dualistic thought and the spiritual, intuitive knowledge of unity, through which one gains a state of one-pointedness, where the knower, the process of knowing, and the known become one. The physical gesture is accompanied by the utterance, namashkar (Sanskrit), or vannakam (Tamil) literally meaning, "I bow to you". Both terms inhere of reverence, worship, homage, and salutation. Thus cumulatively, the utterance and gesture of the Hindu traditional greeting means: "The divinity within me salutes the divinity within you."

Further support for the point being made about the author's sympathetic, respectful and informed view of the Hindu may be derived from his portrayal of specific Hindu ceremonies. In his depiction of the marriage between Maniam and Malini, an impressive array of rituals and practices is conveyed, along with clarifications. The following are mentioned in the extract to demonstrate this: the Gatra-haridra-bodily purification with saffron, perfumes, and flowers; the bindi-the sacred dot marking the third eye; the sari and dhoti-made of kasa material from Mysore; the use of mango leaves and its association with kama god of love; anukurarppanam-a ritual of worship; purana-kunbham, opiations to the gods for prosperity; nalanku -smearing of saffron, yellow powder and sandalwood to signify goodness 
and reward in marriage; the exchange of garlands and the tying of the thali. The author's detailed knowledge of the rituals, and their significance, is quite remarkable. Additionally, this may be seen from the following example, which is a depiction of the ultimate ceremony, the Vedic ritual of homa:

Maniam kemudian memimpin Malini mengelilingi api perkahwinan dan melakukan homa. Sebagai memohon restu, mereka bersama-sama melangkah tujuh langkah di hadapan api upacara itu. Menurut kepercayaan, tiap-tiap langkah itu melambangkan makanan, kekuatan, kekayaan, kebahagiaan, keturunan, binatang ternak, dan kesetiaan. (p. 228)

(Then Maniam led Malini around the sacred marriage fire in performance of the homa. In supplication for divine blessings, together they took the seven steps before the ceremonial fire. According to belief, each step symbolised food, strength, wealth, happiness, progeny, livestock, and loyalty.)

From the foregoing textual evidence, it may be said that far from being the work of a writer who rides roughshod over Hindu sensitivities, as one of the accusations levelled at Abdullah Hussain has been, it shows instead, a stance of respect, harmony, and concord.

The discussion in this section may be ended by a final example. This moving passage echoes all the characteristics and significance of connection between self and Self in the esoteric view of man and God, as has been pointed out in a preceding section. In this incident, in a moment of selfdiscovery, Seman feels immensely grateful to Maniam. In spite of being of a different race, Maniam has proven to be a faithful friend of Seman's late father. Therefore, Seman sees him as more than a friend, a surrogate father even, and as a guardian.

Dalam perjalanan pulang itu, dia berfikir sendirian. Betapa hebatnya persahabatan antara bapanya dengan orang itu. Dia tidak pernah mengetahui ada perhubungan persahabatan antara orang yang berlainan bangsa yang sedemikian rupa....

Tiba-tiba ... dia teringat akan Tuhan. Dia teringat akan ibunya. Barangkali ibuku sedang sembahyang maghrib... Siapa tahu kuasa Tuhan? Dia teringat akan Maniam. Baik sungguh hati orang India itu. Barangkali itu pun kuasa Tuhan. Sudah beberapa puluh tahun dia berpisah dengan bapaku, aku pun belum ada lagi, tetapi dia masih ingat. Dia mahu menolong aku. (p. 293) 
(On his way back, he was thinking to himself. What a remarkable friendship it was between his father and the man. He never knew there could be such a connection of friendship between people of different races ...

All of a sudden ... he thought about God. He thought of his mother. Perhaps my mother is performing the solat maghrib (the evening prayer) .... Who would know the power of God? He thought of Maniam. That Indian man is truly good-hearted. Perhaps that too was the power of God. He was separated from my father more than twenty years ago, I wasn't even born yet, but still he remembered. He wanted to help me.)

In thinking, remembering, and associating himself with the omnipresent, omnipotent God, and with his parents, and with Maniam all at the same time, Seman experiences a profound sense of unity. He and Maniam are kindred spirits. This experience may be related to, and expressed succinctly by, the Hindu scriptural dictum on God's omnipresence: I pervade the entire universe in my unmanifested form ... Behold my Divine Mystery!

From the examples related to religiosity in this section, it may be construed that the traditional esoteric view that accepts both (religious and ethnic) plurality and (cultural) similarity and a shared weltanschauung is presented. This is consistent with an inclusive and universal outlook on life. Furthermore, the outward journey of Maniam and his companions-by ship, across water, for a better life in a foreign land, may be interpreted symbolically. The voyage over water represents a challenge that serves as a purifying factor, the ship as man's body in which one crosses the ocean of life and of undergoing transitions from one stage of consciousness to another, and the entire journey, as a human quest for a return to his original nature. Maniam finds harmony with his new environment in Malaya. It is a quest that is facilitated by a harmony between the self and the other that observes the differences between religions, yet transcends them, according to the Ideal that man's spiritual quest harmonises his earthly journeys. And thus the self becomes integrated with the other. The "I" is at par with "you", or in spiritual terms, "I am you." Beyond that, Abdullah Hussain's portrayal in all of the examples on religion and the vertical connection comes across as an informed view and even as an insider's view, rather than that of an ignorant outsider who takes a derogatory view of the Hindu. 


\section{The horizontal connection}

Having gained an understanding of the relevant Hindu doctrines, their central position to the esoteric viewpoint, and how they determine the reading of elements in the nature of the vertical connection in Interlok, it is equally interesting to pursue the horizontal connection as may be discerned in the novel. And that is, we are proceeding from consideration of "the Ideal" to "the real" as portrayed in the novel. This involves a study of the characters in the context of both, the position of man and his being in the world, and the interaction of man with his environment, specifically his fellow men. Again, textual evidences will be drawn towards supporting the objective of demonstrating the author's viewpoint.

The section on Book Three, "Maniam's Family" is a focus on the Indian character, Maniam and the story of his life in Malaya. It starts with a seemingly innocuous passage, in which the author states that:

Di dalam kapal ini dia tidak susah. Sebahagian besar daripada penumpang dek yang bersama-samanya itu bercakap dalam satu bahasa sahaja, bahasa Tamil. Mereka yang dari arah ke utara sedikit bercakap bahasa Malayalam atau Telegu tetapi hampir semuanya tahu bahasa Tamil. Malayalam dan Telegu pun berasal dari rumpun bahasa Dravidia. (p. 211)

(He had no problems on the ship. A majority of the passengers who were together on deck spoke only one language, Tamil. Those who came from a little further north spoke Malayalam or Telegu, but almost all of them knew Tamil. Malayalam and Telegu too, originated from the Dravidian language.)

This information establishes a shared linguistic basis among the passengers, while maintaining that geographically, they have different origins. Thus the geographic plurality is offset by linguistic similarity. Earlier, it was stated that the passage is "seemingly innocuous"-this is for the specific reason that, as he sails towards an anticipated "promised land", the author introduces the element of caste, with specific mention of the "paria". Thus, an insidious and sinister social element rears its head over Maniam's horizon: the yoke of the caste system which he bears, as someone from a "low" caste, referred to as "paria". In the passage, one of the "push" factors that drive Maniam and his companions out of their homeland conveys damaging social overtones of the "mother country": 
Satu perkara besar yang membuatkan mereka senang bergaul adalah kerana mereka tergolong dalam satu kasta Paria. Mereka tidak perlu takut akan mengotori sesiapa kalau bersentuhan. Mereka juga bebas bergaul. (p. 211)

(One important factor that made them relate easily with each other was that they were all from the same Pariah caste. They did not need to fear "soiling" anyone by accidentally touching them. They could also interact freely.)

The above element has been the subject of bitter debate and objection from many among the Indian population, and therefore warrants detailed study, both of factual and fictional realities. The original, spiritual foundation of the concept of varna as explained in a foregoing section, and the role and function of the pariyars, spelled as "paria" in Interlok, may be recalled here. If one were to perceive the context of its occurrence in the novel in a derogatory sense, as many have done, the question may be asked: why not reclaim the other, positive sense, and acknowledge the paria's exalted glorious origins, since it inheres both? This will be amply evidenced in the following discussion. In this instance, what dictates in which sense an expression should rightly be understood and interpreted, other than the text itself? The fact is, it is difficult to find any derogatory denotative or connotative sense in this passage.

First, the freedom of movement and of interaction experienced, as mentioned in the above extract, is significantly positive for the migrant Indians in Malaya. This is conveyed several times in different ways, soon after it is introduced:

... Dia gembira hidup di negeri ini kerana untuk pertama kali dalam hidupnya dia berasa dirinya sebagai manusia seperti orang lain. Di sini dia tidak sahaja bebas bercampur gaul dengan orang lain sama sebangsanya, malah dia tidak takut dengan pantang larang yang terdapat di negaranya apabila seorang India daripada kasta rendah menyentuh orang India daripada kasta tinggi ... sehingga dirinya dan orang-orang yang sekasta dengannya menjadi lebih hina daripada binatang. (p. 218)

(He was happy in this land because for the first time in his life he felt that he was a human being, just like other people. Here there was not only freedom of interaction with people of his own kind, but also a lack of fear for the taboos that prevailed in his own country when an Indian from a low 
caste touched another Indian from a high caste ... to the extent that he and others of his caste became more lowly than animals.)

To begin with, it may be said that anyone who is against social discrimination would agree that from the above passage, Maniam's situation is abhorrent. On the page that follows, the author elaborates,

Di negeri ini, orang daripada keturunan kasti tinggi, kasta Brahma, memakai punul ... tetapi dia tidak takut menyentuh orang itu. Dia boleh membeli barang daripada penjaja dengan memberikan wang dari tangan ke tangan; tidak seperti di negaranya, dia mesti meletakkan wang itu di suatu tempat dan penjaja itu akan menyiram wang itu dengan air sebelum diambil ... . (p. 219)

(In this country, people from a high caste, the Brahma caste, wore the sacred thread ... but he was not afraid to touch such people. He could buy things from hawkers by placing the money in his hand onto theirs; unlike in his country, he had to put the money in a particular place and the hawker would sprinkle water over it before picking it up ...)

Again, a portrayal of the reality of discrimination "in his country" (India) is apparent. It underscores the disparity between people of "high" and "low" caste. And definitely, it portrays the insulting and repulsive behaviour of the "high", "Brahma" caste, matched by the demeaning obsequiousness that Maniam and his companions were compelled to observe, back home.

However, it is necessary to be judicious and discerning, before attributing a disparaging viewpoint in the novel to the author's intent, and the argument for discernment between real and imagined insult, can proceed on the basis of three points. Firstly, recognition has to be given that the author is correct in his portrayal. He is stating facts, presenting truths fictionally, about a factual situation that is also "the real", which existed then and now in India. Even today in Malaysia, among Indians who do still endorse and observe caste as indication of a person's social status in life, and to determine how an individual is to be treated. Second, rather than take exception to the passage itself or the author, one should rightly direct objection to the phenomenon of discrimination. This is because the author is exposing an abhorrent situation, not condoning it. Thirdly, to balance the scale as it were, Abdullah has implicitly and explicitly shown in the novel, that the Indian characters rise above their initial position in terms of status, knowledge and individuality. The following examples from Interlok will illustrate this: 
... Sudah 21 tahun dia berkhidmat di kebun ini. Mula-mula sebagai kuli biasa, sekarang dia menjadi tandil. Dia berasa puas hati dengan pekerjaannya. (p. 286)

(He had served for 21 years in this estate. At first as an ordinary labourer, and now as a supervisor to the labourers. He felt contented with his job.)

The migrant Indians develop for the better, they improve and progress. This is also true in the real world: Success stories of "low caste" Indians succeeding in Malaya/Malaysia abound everywhere. The original Indian migrants are on record for their very important role in the building of roads and railways, and the success of the rubber industry in this country. And this is amply and accurately portrayed in the novel. The truth is, a vast number of Indians have prospered, risen above their original status, and some have achieved top positions, as close to the heart of government more than anyone can achieve. Is this not a source for pride?

Thirdly, in the novel, Maniam's interaction with "the other", the Malay, shows advance and progress, not only in social position, but in stature as a human being. In the past it was Musa, the Malay, who saved the life of the Indian Maniam, when the latter was almost killed by his own people, 20 years before. And in the present, Maniam is helping Seman, the son of Musa by giving him a job, and providing Mak Limah, Musa's widow, a place to stay.

Tepat seperti janjinya, Maniam menunggu kedatangan mereka. Lama Maniam merenung muka Mak Limah. Dia ternampak-nampak Musa yang telah menolongnya, dan dia teringat Malini dan anaknya. Dia nampak tanda-tanda penderitaan pada wajah perempuan tua itu, tetapi cuba disembunyikan di sebalik air mukanya yang tenang. (p. 296)

(True to his promise, Maniam waited for their arrival. For a long while Maniam looked at Mak Limah's face, reflecting. He visualised images of Musa who had helped him, and he was reminded of Malini and his child. He saw traces of suffering on the old woman's face, which she tried to hide behind a calm expression.)

In the process of helping each other through the years, the Indian and the Malay transcend the ethnic and religious barriers dividing them. The nature of their friendship is such that there is not only a deep mutual respect for each other, but also a profound bond of empathy and identification through 


\section{MALAY LITERATURE}

shared sorrow. Undoubtedly, to express it in Hindu spiritual terminology, this displays the spirit of "I am you."

To reinforce the argument in defence of the context in which the caste system is conveyed in Interlok, one may acknowledge certain facts. One, the Indian caste system and two, Indian immigration to Malaya. Both are historical facts, the author has not created them himself to denigrate the Indian. Furthermore, owing to political factors and social beliefs and practices, caste-based discrimination is still practised and observed among Indians, both in India today and among migrant communities of the Indian diaspora, including in Malaysia. However, caste-based discrimination/social discrimination is not supported by authorities-they have been outlawed in India, based on democratic and secular principles of the nation's constitution. Thus it may be said that the text of Interlok is factually correct in all references to the Indian situation.

To continue with this line of argumentation, from the ease of association/ social interaction and the issue of untouchability portrayed, far from despising "paria" Indians, is apparently a major concern for the author, judging from the frequency and intensity that he portrays it in Interlok. Simply stated, he is championing the cause of the "paria", not denigrating them. He repeatedly conveys a sense of obvious relief in mentioning that, here in Malaya, they find respite from people being "soiled" by touching one another. This is an indirect reference to the issue of "untouchability" of certain castes in India, formerly called Dalits, as has been explained previously. It is historically known that the pariyars in India in the time setting of Interlok, were discriminated against by the other castes of India, and that their socio-economic conditions were deplorable, providing the push factor for their mass migration to Malaya.

Out of a tragic and devastating incident, Maniam finds reward. He is driven out, nearly killed by the people in the estate, yet subsequently, he engages in a deep bond of friendship with Musa (one of the Malay protagonists), which is cultivated through the years. The foundation of this bond is budi, and terhutang budi (to be beholden to someone)/membalas budi (to repay a debt in gratitude), an important part of the Malay social tradition, with profound connotations. This is because of the richness of meanings associated with it. Dwelling on budi, on one level, it means kindness, goodness or welfare. And so the encounter between the friends takes place on a basis of one good turn deserves another-permanently. On a higher level, it refers to good character, conduct, moral, courtesy and modesty, i.e., social attributes that 
are necessary for maintaining harmony and cohesion in any relationship. At the highest level, it includes intelligence, discretion and good sense. In this context, the Malay concept of budi is strikingly similar (both phonetically and semantically) to the Sanskrit word, buddhi, referring to the intellect, which, in the spiritual understanding, is the highest level of man's faculties, and through which he realises and experiences the immediate connection with the Divine. Thus, it may be said that the nature of the friendship encapsulates the entire range of levels, from the horizontal to the vertical connections. Consciously or unconsciously, and even perhaps intuitively, the friends connect at the level of spirituality. At this level, while recognising external differences or differences in substance, they achieve inward unity, identifying with each other in terms of essence.

Towards the end of the novel, we witness the same bond between two individuals of different ethnic entities, sustained and taken one generation further, that is, to their sons. Maniam helps the late Musa's son, Seman find a job and security. Furthermore, after he is reunited with his own, long-lost son, Ramakrishnan (or Rama), Maniam seeks Rama's help and protection from the Japanese, for Mak Limah, Musa's widow. He had left Rama as an infant back at the estate when he had been driven out in disgrace. But Rama is now a grown man, a stalwart of his community, serving dutifully in an honourable occupation as a police inspector (we will revert to an interesting point on this later). Maniam expresses his regard for his Malay friends as follows:

"Engkau tolonglah dia Rama. Dia itu macam saudaraku sendiri. Suaminyalah yang menolong menyelamatkan aku dulu. Kalau suaminya tak tolong, tentulah engkau dan aku tak bertemu lagi. Engkau tak akan kenal bapamu sampai mati. Tolonglah dia, dia tak bersalah seperti aku juga."

("You have to help her Rama. She is like my own relative. It was her husband who saved my life before. If it had not been for him, surely we would never have met again. You would not have known your father for the rest of your life. Please do help her, she is not guilty, just like me.)

There are several points of note here: the relationship is abiding, it is reciprocal, and ethnicity, class and gender have been transcended in this instance. Ultimately, in the expressions "she is like my own ...", and "she is ... just like me", again we find in the relationship, echoes of the spiritual formulation, "I am you." 


\section{MALAY LITERATURE}

At this point, we may return to the subject of Rama. First, in the authorial aspect, I find in the author's choice of name for his character, a specific purpose. Both, his name, and his situation, is reminiscent of the Hindu mythical Rama, banished to exile in the forest for a crime he did not commit, and re-emerging after 40 years. Similarly, our hero, Rama is lost (or exiled), from the narrative since infancy, and subsequently re-emerges as an adult before he is reunited with his father. Secondly, the character's name is spelt as "Ramakrisynan", a Malay version of the Indian name, conveying a sense of harmonisation and integration. That is, Abdullah has-consciously or unconsciously-appropriated the name. From a hermeneutic viewpoint, through appropriation, he has made the other his own. Second, in the textual aspect, the character, Rama is portrayed as a police inspector. This gives room to interpret his role as a kshatriya, a protector of the weak from harm, precisely what he endeavours to do for Seman and Mak Limah. Moreover, it inheres transitional stages. His lineage is from a labourer community (sudra), and he is born and bred in the estate environment. At maturity he moves on to being a police inspector (kshatriya). And at the close of the story, he is poised to take on a leadership role (brahmin) in his community. The following extract, from the viewpoint of Raman, the school teacher from India, is revealing:

Daripada Ramakrisynan dia mendengar penerangan tentang keadaan politik yang sedang berlaku di negeri ini.

“... Kalau kita tak pulang lagi ke negara India, kalau kita mahu menjadikan negeri ini tanah air kita, kita mesti berbuat sesuatu," kata Ramakrisynan. kita? ...

"Ya," ujar Raman. "Kita mesti berbuat sesuatu. Di manakah pemimpin

"Saya sebagai orang yang lahir di sini akan menjalankan tugas saya sebagai bakti saya pula," kata Ramakrisynan.

...Kata-kata itu menjadi petunjuk kepadanya dalam menentukan garis yang akan dilaluinya dalam masa beberapa tahun ini. Dia orang perjuangan ... Dia nampak suatu tenaga yang besar tersimpan di perkebunan. Tenaga ini harus digunakan sebaik-baiknya. (pp. 394-95)

(From Ramakrishnan he heard explanations about the political developments that were taking place in the country.

“... If we don't return to India, if we want to make this our homeland, we must do something," said Ramakrishnan.

"Yes," Raman answered. "We must do something. Where are our leaders?"... 
"As someone who was born here, I will carry out my duties in the form of service," said Ramakrishnan.

... His words were an indicator for him in determining the path to follow over the next few years. He was part of the struggle ... He could see plentiful resources in the estates. This resources must be harnessed for the best possible purposes.)

Although Raman seems the most likely candidate as the leader of the Indians, it is Ramakrishnan, the protector of the community, who also provides "explanations about political developments", voice out the view that "we must do something", is willing to "carry out my duties in the form of service", and functions as "an indicator" to the leaders. In all of these, he is a man of action, a thinker, planner, leader, in short, a self-realised brahmana.

Ramakrishnan epitomises the idea of mobility in the concept of varna. Furthermore, by fulfilling his destiny or dharma through various stations in life, he strives to perfect himself, like the mythical Rama, whose name he bears. In the Hindu scriptures, Rama (whose kshatriya lineage is wellknown in the Ramayana), is a Divine avatara (of Vishnu), embodying the Perfect Man (adi purusha) in human form, whose descent to the world shows man the path of ascent by which to return to his divine origin. Essentially, Ramakrishnan proceeds from the real to the Ideal. He takes the way of the warrior to its full circle. And thus, hopefully, the disparagement associated with the portrayal of caste in the book may be laid to rest.

\section{Interlok in Malaysian society}

Based on the role of the adikarya in a traditional setting as explained in a preceding section, the role of Interlok in our society based on the understanding of the Hindu view of the adikarya, will be discussed here. The student's edition, the subject of our analysis, is directed to students of Form Five. The examples and arguments have afforded us a glimpse of the novel that does not show any truth in the accusations being made. Other instances are freely and frequently found in the novel. Besides both the view of man and the view of God lend themselves easily to a Hindu esoteric lenses. What we can see of the issue being addressed by the novel is the self and the other in harmony and affinity, conveyed by the Malay-Muslim author's position of empathy and identification with the fortunes and misfortunes of the Indian-Hindu as one of the focal points of the novel. 
There remains the question of aesthetics, or the necessity for beauty and truth in a work of art. To me, the previous extracts used as examples in this essay are essentially beautiful, if beauty constitutes refinement, truth, universality, reality, sincerity, veracity, etc., both in terms of the text and position of the author. Moreover, observe the diction in the following paragraph, in which the passage comes alive with sensual effects of sight, sound and touch:

Tempat itu agak tinggi. Angin sepoi-sepoi bahasa yang terlepas menerusi celah-celah batang getah itu mengulit-ulit tubuhnya. Nyaman dan tenteram ... Sesekali terdengar bunyi buah getah masak yang pecah. Sesekali daun getah tua gugur menimpa pipi dan kepalanya. (p. 287)

(The place was quite far above the ground. Gentle whispers of the breeze that escaped through gaps between rubber tree trunks lulled and stilled his body into a slumber. It was refreshing and quiet and restful ... Once in a while there were the cracking sounds of ripe rubber seeds bursting. Once in a while dead leaves from the rubber trees fell, landing softly on his cheeks and head.)

Beyond the beauty of expression, one may find glimpses of saccidananda (truth-consciousness-bliss) in the description: Maniam seems cocooned in a timeless dimension, in a place "far above the ground", i.e. an elevated place physically, and possibly an elevated state of being. He experiences a passive "inertia", which still both the sense of time and action, and reminiscent of sahajya, nothingness, stillness, quietitude (stira, stitah), which is an original state of the soul. This constitutes a contrast, different from the portrayal of Maniam in previous episodes of active "battle" and struggle in the novel. In fact, contrasts are collapsed (this is the quality of the state of samadhi, where all duality is removed) through juxtaposition, e.g., sound ("cracking") and silence ("quiet and restful"), the vibrancy of life ("ripe rubber seeds bursting open") and the inevitability of death ("dead leaves fell"). Then there is acceptance of both ("landing softly"), and his immediacy with both ("...on his cheeks and head"). Together, the elements build up esoteric undertones in this passage, reminiscent of the meditative state of samadhi.

There are numerous passages of such beauty and richness in the novel. Therefore, it may be said that even in its abbreviated form, Interlok fulfils the role expected of an adikarya. As a school textbook for young readers, 
it is easy to spot the harmonious, inclusive view, the timeless truths, the universal human tragedies and triumphs that educate the readers-to quote the novel-about "the best possible purposes" to which human beings can put their lives. ${ }^{4}$ This is especially so if the young readers are trained, as are literary critics and students of Literature as a subject, to analyse texts in the ways that have been done here. Furthermore, the novel is part of the Malaysian literary canon, and a prescribed textbook, written by an author who holds the stature of National Laureate (Sasterawan Negara) and winner of the Southeast Asia Write Award. By virtue of all of the textual, extra-textual and meta-textual attributes, of which evidence has been presented above, Interlok qualifies for the label of adikarya. Therefore, the author should be respected and honoured, and his work held in high regard. Simply put, to burn the book, demand for it to be withdrawn, or revise a single word of it, as some Malaysian Hindus have demanded would be tantamount to irreverence, a violation of the sacrality of an adikarya, similar in cosmic effects to the burning, neglect or mutilation of a statue of Saraswati. A Hindu should not act in ignorance, demanding that the book be violated. As Saraswati is the embodiment of $\mathrm{Vac},{ }^{5}$ the Goddess of speech and learning (and thereby the written word, of which the book is an embodiment), a Hindu should not venerate Her merely with outward rituals without understanding the underlying philosophy behind the ritual which celebrates learning, creativity and inspiration and is not merely the worship of an idol.

One may draw the discussion to a close on an observation about the title of the novel with regard to the question of unity that has been evidenced in this section. Although Interlok is the transliteration of the English word, "interlock", there is an interesting possibility in the phonetic resemblance in the original with the Sanskrit word lok or loka, meaning worlds or realms. From what we have seen, the unity of the author's world of Interlok not only relates to cultural encounters between the characters. It also applies to whole worlds or realms, the physical, the geographical, the metaphysical and the spiritual as well.

\section{Conclusion}

This essay has attempted to provide an affirmative view of Interlok, based on evidences from the text, from the Hindu spiritual viewpoint, and the Traditionalist view of universal, metaphysical truths. It has shown that by offsetting ignorance with knowledge, referred to as "the sword of wisdom", 
and by the capacity of discernment between the real and the Ideal, one is enabled to hold a fair and just viewpoint. Furthermore, from the evidences, it is not the author who has disparaged the Indians. The controversy has arisen from not wanting to acknowledge certain facts, certain truths about the history and origins of Indians in Malaya/Malaysia. Considering the facts and history, to be known as an immigrant is not derogatory. On the contrary, it should be a source of pride that one can prevail over humble beginnings to achieve the heights of success and authority, both in an individual capacity, and as contributors to the nation. Similarly, rather than take offence at the portrayal of caste and creed in the novel, a view through esoteric lenses further demonstrates that the author understands the deeper meanings of the Hindu culture and religion. This enables one to separate affirmative facts, or the Ideal that prevails in the book, from the imagined insult and offence, or "the real" practices of certain quarters, perhaps to forward their own agendas. The author's standpoint clearly transcends racial, political, historical, nationalistic, ideological, social, cultural, intellectual agendas. It is instead, a simple, humanitarian, intuitive will towards integration.

Both the literary analysis and the esoteric reading yield the same conclusion: the author has demonstrated a profound knowledge and respect for his subject-the Indians. To accuse him of disparagement or gross inaccuracy, and to have caused him pain by so doing, is unjust. I would say that an apology is the least that can be offered in the name of justice. For the fact is, if one can battle and prevail over ignorance and injustice, one can reclaim one's true nature and achieve unity-with God, man, and the environment-which is undoubtedly a prize worth striving for in a world of disharmony and discord.

\section{Notes}

1 The original novel was published in 1971. However, it was abridged to fit requirements as a textbook for the literature component in the Bahasa Malaysia subject for Form Five students in Malaysian schools. Therefore the text referred to in this essay is this student edition also entitled Interlok, published by Dewan Bahasa dan Pustaka, 2010, which has been the subject of dispute.

2 Explanation of the doctrines has been adapted and summarised from the writer's accounts in an open distance-learning course module. See, Lalita Sinha (2010), World Religions, Wawasan Open University, Penang, Unit 3, pp. 4-16. 
3 All the examples will be quoted from the original text in Malay, accompanied by the writer's own English translations.

4 It was quite enlightening to note that in a forum to discuss Interlok held in USM recently, among all the adult reactions and academic viewpoints on what should and should not be read by school children, a young Indian schoolgirl stood up to point out: "You people underestimate our intelligence. We are young, but we too, know how to differentiate the right from the wrong."

5 Interestingly enough, the Malay word, wacana, meaning speech, discourse, and published works is a derivative from the Sanskrit word vac.

\section{References}

Abdullah Hussain, 1971. Interlok. Dewan Bahasa dan Pustaka: Kuala Lumpur.

Coomaraswamy, Ananda K., 1952. Contemporary Indian Philosophy, ed. S. Radhakrishnan and J.H. Muirhead, London.

Coomaraswamy, Ananda K., 1971. The Dance of Shiva: Fourteen Indian Essays. Revised Edition. New Delhi: Sagar Publications.

Goswami, Satsvarupa Dasa, 1977. Readings in Vedic Literature: The Tradition Speaks for Itself. Los Angeles: The Bhaktivedanta Book Trust.

Guenon, Rene, 1995. Fundamental Symbols: The Universal Language of Sacred Science. Translation by Alvin Moore, Jr. Rev. and Ed. Martin Lings. Oxford: Quinta Essentia.

Hutton, J.H., 1980. Caste in India. New Delhi. Oxford University Press. Kancha Ilaiah, 2005. Why I am not a Hindu: A Sudra Critique of Hindutva Philosophy, Culture and Political Economy. Calcutta: Samya. Molloy, Michael, 2002. Experiencing the World's Religions: Tradition, Challenge \& Change. 2nd ed. California: Mayfield Publishing Company.

Oldmeadow, Harry 2005. "The Heart of Religio Perennis: Frithjof Schuon on Esotericism". Introduction to The Betrayal of Tradition: Essays on the Spiritual Crisis of Modernity. Ed. Harry Oldmeadow, World Wisdom.

Online edition of India's National Newspaper, (2001, August 14). "Beef Eating: Strangulating History.” Retrieved 6 June 2011, from http://www. hinduonnet.com/2001/08/14/stories/13140833.htm.

Oxford Dictionary, 1989. Second Edition. Oxford University Press.

"Paraiyar" in Wikipedia, the free encyclopedia. http://en.wikipedia. org/wiki/Paraiyar. Retrieved on 5 January 2011. 
Schuon, Frithjof, 1975. The Transcendent Unity of Religions. Harper \& Row Publishers, Inc. New York. N.Y.

Sinha, Lalita, 2010. World Religions, Wawasan Open University, Penang, Unit 3, pp. 4-16.

Sivaraman, Krishna (ed.), 1995. "Introduction" in Hindu Spirituality: Vedas Through Vedanta. New Delhi: Motilal Banarsidas.

Smith, Huston 1991. The World's Religions: Our Great Wisdom Traditions. New York: Harper Collins Publishers.

Stoddart, William 2008. "Tradition and Modern Civilizations" in Remembering in a World of Forgetting: Thoughts on Tradition and Postmodernism. World Wisdom Inc. Online library www.worldwisdom. com/public/library/default.aspx. Retrieved on 12 June 2011.

The Bhagavad Gita, 2002. Translation and commentary by Srimath Swami Chidbhavananda. 20th Impression. Tapovanam Series 80. Trichirapalli, India.

Zailan Moris, 2000. "The Image of Man in the Major Religions of The World" in Jurnal Ilmu Kemanusiaan, October 7, pp. 73-80. 